\title{
THE AMPHIBIANS AND REPTILES IN KOMODO NATIONAL PARK AND THE SURROUNDING AREA
}

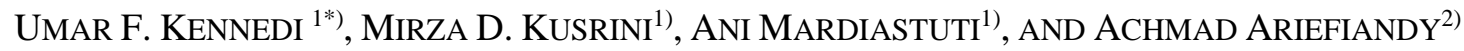 \\ 1) Department of Forest Resources Conservation and Ecotourism, Faculty of Forestry and Environment, IPB \\ University, Bogor, 16680, Indonesia \\ 2) Komodo Survival Program, Denpasar, 80117, Indonesia
}

*Email: umarfhadlikennedi@gmail.com

Accepted March 22, 2021 / Approved November 30, 2021

\begin{abstract}
The Komodo National Park in the Wallacea region is the komodo dragon's primary habitats. Published report on the herpetofauna of this national park is mostly concentrated in Komodo island. To increase our knowledge of amphibian and reptile communities in Komodo National Park, we conducted a herpetofauna survey in Komodo and Rinca Island and the nearby coastal area to assess diversity and community similarity and developed a complete checklist of the herpetofauna of Komodo National Park. We conducted a Visual Encounter Survey and put glue traps from February-April 2018 at six locations on Komodo Island (Loh Liang, Loh Wau dan Komodo Village) and Rinca Island (Loh Buaya, Loh Baru, and Rinca Village); and three locations on coastal areas of Flores (Labuan Bajo and Cumbi Village) and coastal area of Sumbawa (Sape) adjacent to Komodo National Park. We found seven species of amphibians and 22 species of reptiles and, however, only two species of amphibians and 18 species of reptiles were found in Komodo and Rinca Island. The highest diversity $\left(H^{\prime}=2.14\right)$ is in Loh Buaya (Rinca Island), and the highest evenness $(E=0.58)$ is in Loh Baru (Rinca Island). The highest similarity occurs between Komodo Island and Rinca Island (IS =0.8). Using data from other research, we have compiled a list of four species of amphibians and 39 species of reptiles occurring at three main islands of Komodo National Park: Komodo island, Rinca Island and Padar Island.
\end{abstract}

Keywords: Herpetofauna diversity, Komodo National Park, Lesser Sunda Islands

\section{INTRODUCTION}

Komodo National Park is a conservation area in the Wallacea region, known as the region with low biodiversity but rich in endemicity (Monk et al., 1997). As a conservation area, Komodo National Park primarily designated to preserve the charismatic and threatened species, komodo dragon (Varanus komodoensis), and its habitat. The national park comprises two large islands (Komodo and Rinca) and three smaller islands (Padar, Gili Motang, and Nusa Kode) inhabited by Komodo dragons. These islands are located between Sumbawa and Flores islands.

Since the national park focus is the conservation of the komodo dragon, there is a lack of study on the other species of reptiles or amphibians (see Ardiantiono et al. 2018, Ciofi et al., 1999, Jessop et al. 2018, Purwandana et al., 2016). During his research on the behavioral ecology of the komodo dragon (from 1969 to 1973), Auffenberg collected specimens of amphibians and reptiles in Komodo Island using accidental sampling. He reported two amphibians and 28 reptiles, including marine species in Komodo Island. For more than 30 years afterward, there has been no other report on amphibian and reptile species of Komodo National Park until Wahyuni (2012) reported 16 species of reptiles from 7 families from Padar Island. A few years later, a booklet on amphibian and reptile of Komodo National Park was written by Somaweera et al. (2018), which listed four species of amphibians and 39 species of reptiles, including marine species. The list was produced mainly based on accidental sighting and did not specify the distribution of the species within the islands of Komodo National Park. The list also did not identify the most abundant species and the herpetofauna community of each island.

Labuan Bajo in coastal Flores Island and Sape in coastal Sumbawa Island are the main entry points for tourism activity in the Komodo National Park. High mobility of sea transport between locations is considered as the pathway for the distribution of invasive species (Hulme et al., 2008). To increase our knowledge of amphibian and reptile communities in Komodo National Park, we conducted a herpetofauna survey in Rinca dan Komodo Island and the adjacent coastal area to assess the diversity and the similarity of the herpetofauna of Komodo National Park with the surrounding coastal area from the nearby mainland. Using additional information from Somaweera et al. (2018), Wahyuni (2012), and Auffenberg (1980), we then developed a complete list of amphibian and reptile of Komodo National Park.

\section{RESEARCH METHOD}

We conducted field surveys in six locations within two main islands of Komodo National Park and three locations outside of the national park. The locations within the national park were Komodo Village, Loh Liang, Loh Wau (Komodo Island); Rinca Village, Loh 
Buaya, Loh Baru (Rinca Island); and locations outside the national park were Sape (coastal Sumbawa Island), Labuan Bajo, and Cumbi village (coastal Flores Island) (Fig 1). The habitat characteristic of each location is similar, mostly dry, and arid valleys with an elevation between 2-270 $\mathrm{m}$ a.s.l. The freshwater source was available in Komodo Village, and Loh Wau with stream flows throughout the year. However, in Loh Liang, there is no water sources, and the stream only flows during the rainy season. All locations in Rinca have water all year round. Labuan Bajo and Cumbi Village (Flores) are also considered dry; however, they were relatively wetter than Komodo and Rinca Islands. The Cumbi Village is near Wae Wuul Nature Reserve, a Komodo dragon habitat outside the national park (Ariefiandy et al., 2015). Water sources are plentiful and flow throughout the years in the area. Similarly, Sape in the eastern part of Sumbawa is also wetter, with water that flows all year round. Sape and Labuan Bajo are the main entry points to enter Komodo National Park (Figure 2a, b, c, and d).

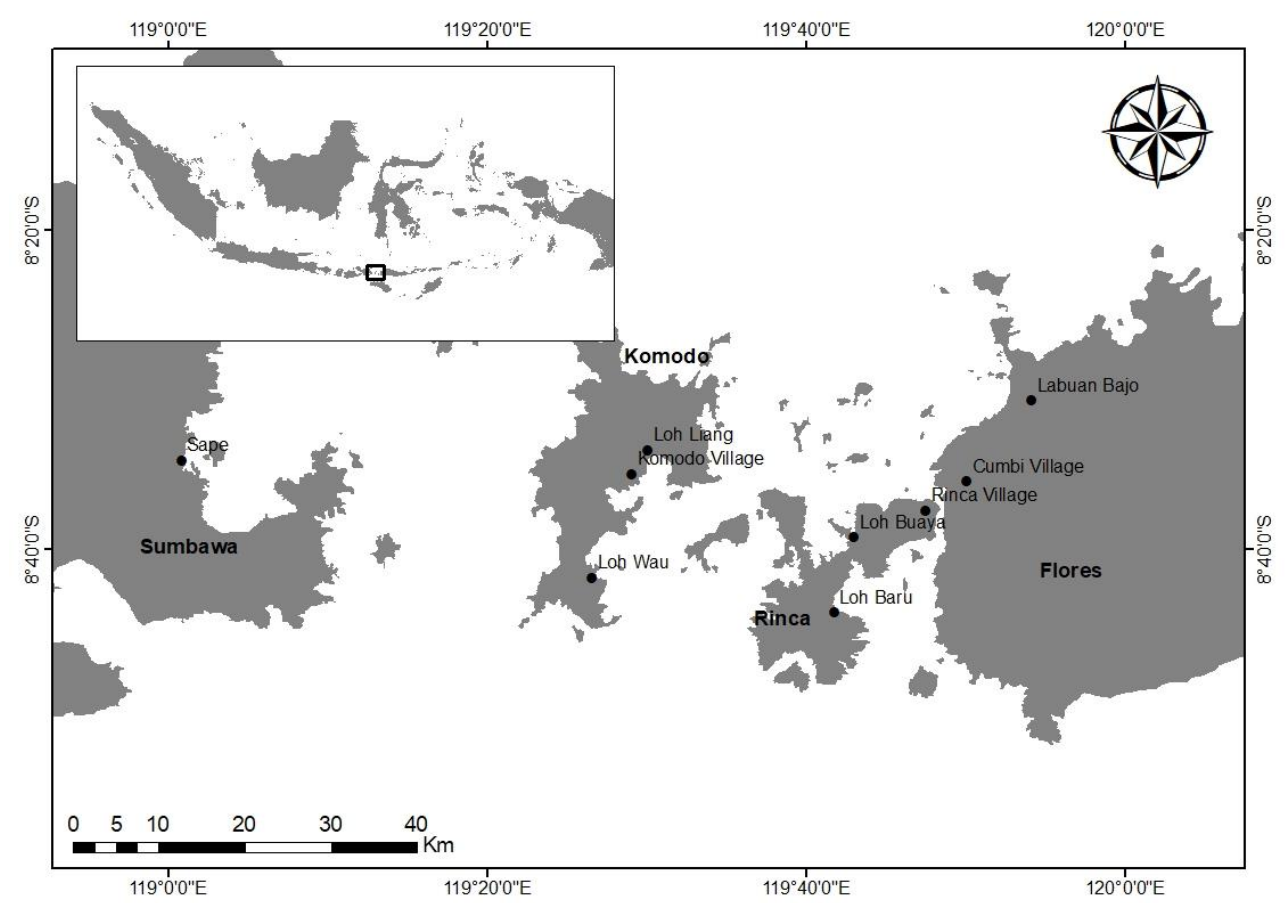

Figure 1 Map of Komodo National Park and its adjacent coastal area of mainland Flores and Sumbawa
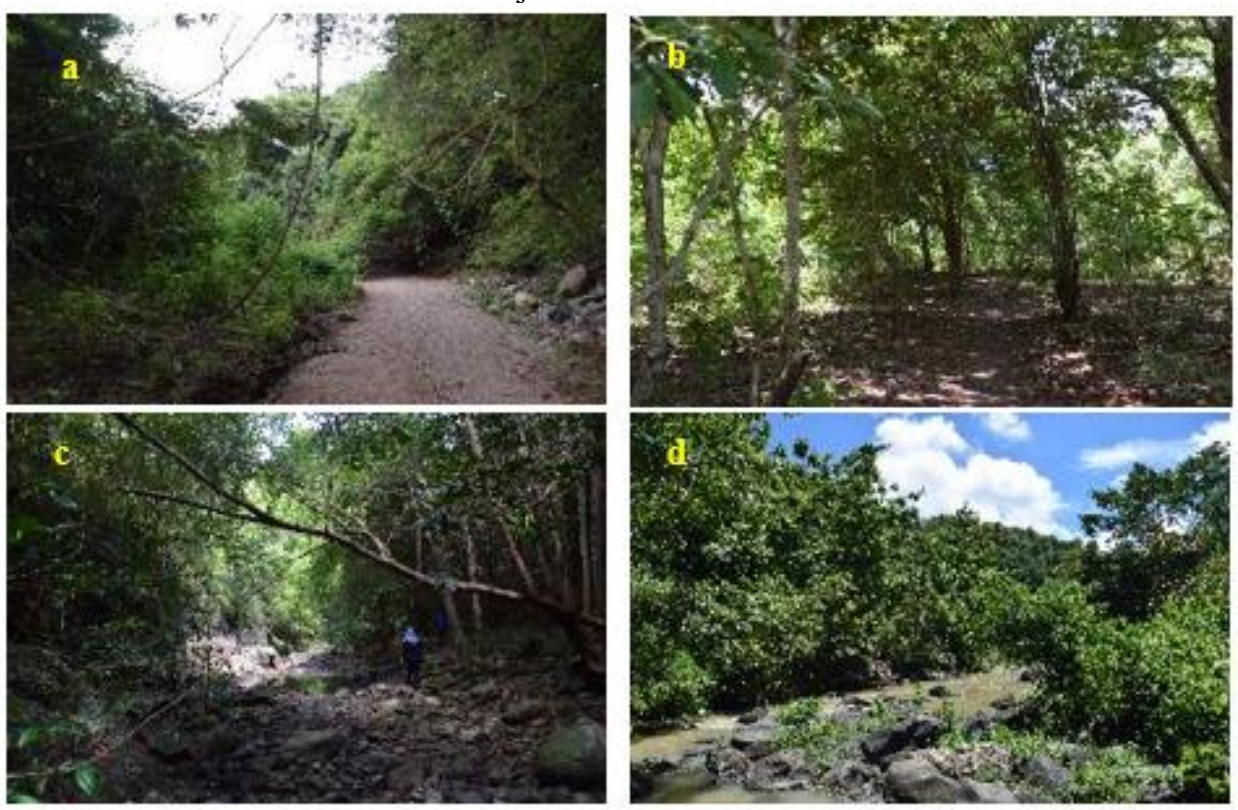

Figure 2 Habitat condition in Loh Liang, Komodo Island (A), Loh Buaya, Rinca Island (B), Cumbi Village, coastal Flores Island (C), and Sape, coastal Sumbawa Island (D). 
Data were collected at the end of the rainy season in February-April 2018. We concentrated the survey on the area within a maximum range of $100 \mathrm{~m}$ from water sources to make sure that we were able to observe amphibians. A Visual Encounter Survey method (Heyer et al., 1994) was carried out by randomly walking through the selected habitat by two-three surveyors. We actively searched the areas at night (19:00-21:00 Eastern Indonesian Time) on the forest floor, leaf litter, fallen logs, water bodies, and surrounding vegetation. During the day (08:00-10:00), we used a glue trap to capture small lizards and an active search for other reptiles. We put ten glue traps (size $30 \times 30 \mathrm{~cm}$ ) within $\pm 20 \mathrm{~m}$ of each other in locations that serve as a habitat for basking or feeding on the forest floor with leaf litter, stones, or fallen tree trunks. The total effort during the research was 654 person-hours.

We recorded locations, species, and date of capture at the time of capture. Habitat characteristics were noted. Frogs and reptiles were released after examination at the point of capture. Several individuals of amphibian and reptiles were preserved using $90 \%$ alcohol as voucher specimens, especially for species that have not been identified. Specimens were stored at the Museum Zoologicum Bogoriense, Research Centre for Biology, Indonesian Institute of Sciences (LIPI). There was no ethical clearance for collecting specimens as no such document was requested by the park management, other than permit to collect published by the national park management. However, we used guidance from Clemann et al. (2014) for the ethical collection of specimens and Kusrini (2019) for making specimens in an ethical manner. Nomenclature follows the reptile database https://reptile-database.reptarium.cz/ (Uetz and Etzold, 1996) and amphibian species of the world version 6.1 from the American Museum Natural History (AMNH) https://amphibiansoftheworld.amnh.org/ (Frost, 2020).

We constructed a checklist of amphibians and reptiles and grouped it based on Red List IUCN (International Union for Conservation of Nature), CITES Appendix (Convention on International Trade in Endangered Species of Wild Fauna and Flora), and Indonesian Law (Peraturan Menteri Kehutanan and
Lingkungan Hidup nomor 106 Tahun 2018). We developed an accumulation curve for species obtained during each periodic survey, thus omitting species obtained outside sampling time but described in this report.

We measured diversity indices using the ShannonWiener diversity index (H') (Brower and Zar, 1997), Evenness (E), and Jackknife estimator for species richness (S) for each location. Data were analyzed using program PAST version 3.22 except for the Jackknife estimator for species richness (S), which was calculated following Heltse \& Forester (1983). The community similarity index was measured using the Bray-Curtis index (Bray and Curtis, 1957).

\section{RESULT AND DISCUSSION}

\section{Species compositions and relative abundance}

During the survey, we found 29 species of herpetofauna $(n=671)$, consisting of 7 species of amphibians from 4 families and 22 species of reptiles from 10 families (Table 1). We found two endemic amphibians (Limnonectes kadarsani and Oreophryne jeffersoniana) and five endemic reptiles (Draco boschmai, Dendrelaphis inornatus, Coelognathus subradiatus, Malayopython timoriensis, and Varanus komodoensis). Fifteen species are listed as Least Concern on IUCN Red List, 10 species are Not Evaluated, one species is listed as Near Threatened (O. jeffersoniana), and one species is listed as Vulnerable (M. timoriensis), and one species is listed as Endangered ( $V$. komodoensis). There are three species listed in Appendix II CITES: M. reticulatus, M. timoriensis, V. salvator, and one species is listed in Appendix I CITES, $V$. komodoensis (Figure 3).

The cumulative curves for each location differed; however, it tend to increase in all locations (Fig. 4). This indicates that there is a possibility that additional observation will yield other species, i.e., C. subradiatus, B. hoeseli, N. sputatrix, which have been found by the first author outside the sampling time of this research. 

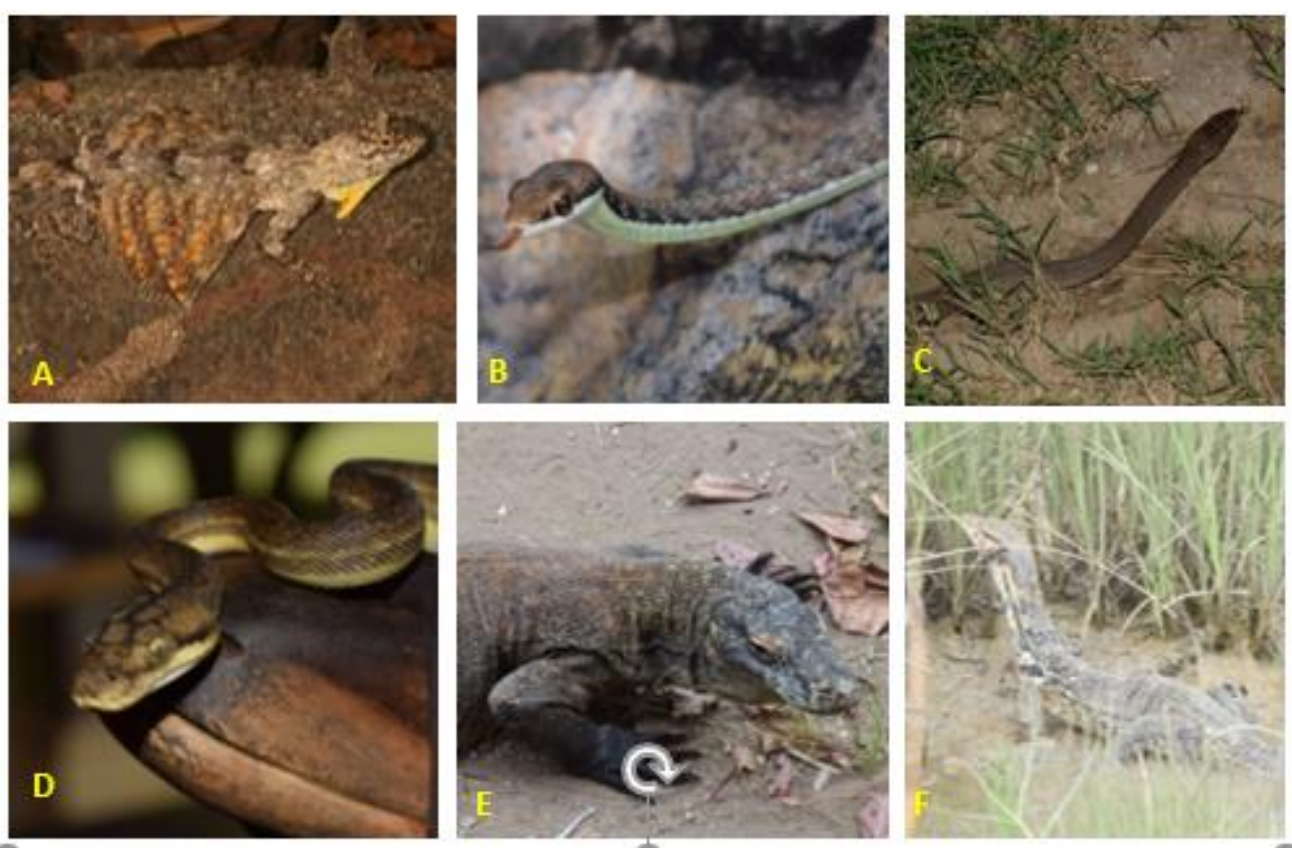

Figure 3 Endemic species of reptile found during survey Draco boschmai (A), Dendrelaphis inornatus (B),

Coelognathus subradiatus (C), Malayopython timoriensis (D), and Varanus komodoensis (E), except for Varanus salvator $(\mathrm{F})$, which is listed in CITES Appendix 2

Table 1 Amphibian and reptile community comparison by location, endemicity (E), and conservation status based on the survey in February - April 2018.

\begin{tabular}{|c|c|c|c|c|c|}
\hline No & 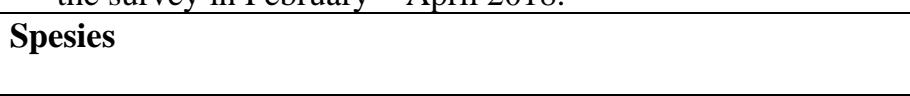 & $\begin{array}{c}\text { Komodo } \\
\text { Island }\end{array}$ & $\begin{array}{l}\text { Rinca } \\
\text { Island }\end{array}$ & $\begin{array}{c}\text { Coastal } \\
\text { Flores }\end{array}$ & $\begin{array}{c}\text { Coastal } \\
\text { Sumbawa }\end{array}$ \\
\hline & AMPHIBIANS & & & & \\
\hline & Bufonidae & & & & \\
\hline \multirow[t]{2}{*}{1} & Duttaphrynus melanostictus (Schneider, 1799) & - & - & - & + \\
\hline & Dicroglossidae & & & & \\
\hline 2 & Fejervarya cancrivora (Gravenhorst, 1829) & - & + & + & + \\
\hline 3 & Fejervarya limnocharis (Gravenhorst, 1829) & - & - & + & + \\
\hline 4 & Fejervarya verruculosa ${ }^{E}($ Roux, 1911$)$ & - & - & + & - \\
\hline \multirow[t]{2}{*}{5} & Limnonectes kadarsani $^{E}$ (Iskandar, Boeadi, and Sancoyo, 1996) & - & - & + & - \\
\hline & Microhylidae & & & & \\
\hline 6 & Kaloula baleata (Muller, 1836) & + & - & + & + \\
\hline \multirow[t]{2}{*}{7} & Oreophryne jeffersoniana ${ }^{E}$ (Dunn, 1928) & - & - & + & - \\
\hline & Rhacoporidae & & & & \\
\hline 8 & Polypedates leucomystax (Gravenhorst, 1829) & - & - & + & - \\
\hline
\end{tabular}

\section{REPTILES}

\section{Agamidae/Lizard}

1 Draco boschmai (Hennig, 1936)

\section{Gekkonidae/ Gecko}

2 Cyrtodactylus darmandvillei ${ }^{E}$ (Weber, 1890)

3 Hemidactylus frenatus (Dumeril \& Bibron, 1836)

4 Hemidactylus platyurus (Schneider, 1797)

5 Gekko gecko (Linnaeus, 1758) 


\begin{tabular}{|c|c|c|c|c|c|}
\hline No & Spesies & $\begin{array}{c}\text { Komodo } \\
\text { Island }\end{array}$ & $\begin{array}{l}\text { Rinca } \\
\text { Island }\end{array}$ & $\begin{array}{c}\text { Coastal } \\
\text { Flores }\end{array}$ & $\begin{array}{c}\text { Coastal } \\
\text { Sumbawa }\end{array}$ \\
\hline \multirow[t]{2}{*}{6} & Gehyra mutilata (Wiegmann, 1834) & + & - & - & - \\
\hline & Scincidae/Skink & & & & \\
\hline 7 & Sphenomorphus melanopogon (Dumeril \& Bibron, 1839) & + & + & + & - \\
\hline 8 & Sphenomorphus striolatus $^{E}$ (Weber, 1890) & + & + & + & + \\
\hline 9 & Cryptoblepharus renschi (Mertens, 1928) & + & + & - & - \\
\hline 10 & Emoia similis $^{E}$ (Dunn, 1927) & - & + & - & - \\
\hline \multirow[t]{2}{*}{11} & Lamprolepis smaragdina (Lesson, 1829) & - & - & + & + \\
\hline & Colubridae & & & & \\
\hline 12 & Lycodon capucinus (Boie, 1827) & + & + & + & + \\
\hline 13 & Dendrelaphis inornatus ${ }^{E}$ (Boulenger, 1897) & + & - & + & - \\
\hline \multirow[t]{2}{*}{14} & Coelognathus subradiatus $^{E}$ (Schlegel, 1837) & - & - & - & + \\
\hline & Elapidae & & & & \\
\hline \multirow[t]{2}{*}{15} & Laticauda colubrina (Schneider, 1799) & + & + & - & - \\
\hline & Homalopsidae & & & & \\
\hline \multirow[t]{2}{*}{16} & Cerberus schneiderii (Schlegel, 1837) & - & + & - & - \\
\hline & Pythonidae & & & & \\
\hline 17 & Malayopython timoriensis ${ }^{E, I I, \#}$ (Peters, 1876) & - & + & - & - \\
\hline \multirow[t]{2}{*}{18} & Malayopython reticulatus ${ }^{I I}$ (Schneider, 1801) & - & - & + & - \\
\hline & Typhlopidae & & & & \\
\hline \multirow[t]{2}{*}{19} & Virgotyphlops braminus (Wallach 2020) & - & + & - & - \\
\hline & Viperidae & & & & \\
\hline \multirow[t]{2}{*}{20} & Trimeresurus insularis (Kramer, 1977) & + & + & + & + \\
\hline & Varanidae & & & & \\
\hline 21 & Varanus komodoensis $^{E, I, *, \wedge}$ (Ouwens, 1912) & + & + & - & - \\
\hline \multirow[t]{5}{*}{22} & Varanus salvator ${ }^{I I}$ (Laurenti, 1768) & - & + & + & + \\
\hline & N amphibian species & 1 & 2 & 7 & 5 \\
\hline & $N$ reptile species & 13 & 18 & 12 & 11 \\
\hline & Number of herpetofauna species & 14 & 20 & 19 & 16 \\
\hline & Jackknife index & 18 & 23 & 23 & 20 \\
\hline
\end{tabular}

Note: endemicity (E), conservation status (CITES, IUCN Red List, and Indonesian Government regulation on Protected species or PP No. 106 MenLHK 2018) for Komodo National Park and its surrounding, Nusa Tenggara, Indonesia (+ present; - absent). I, II denotes Appendix I and II in CITES, \# represents vulnerable in IUCN Red List, * denotes endangered in IUCN Red List, and ${ }^{\wedge}$ denotes protected species

The presence of endemic species and species listed in threatened categories at IUCN Red List or in the protected category, i.e., M. timoriensis, V. komodoensis, and the blue-green T. insularis, which only found in the Nusa Tenggara region, shows the importance of Komodo National Park to ensure the existence of herpetofauna (De Lang, 2011). However, except for V. komodoensis, which is a protected species and well known, the presence of endemic snakes is under threat as snakes are often considered dangerous and thus killed by local people. During the survey, we encountered a dead $T$. insularis, which were most probably killed by the local people. Based on an interview with locals, the blue-green variant of $T$. insularis is often hunted and traded on the island of Sumbawa (Fig. 5).

The highest relative abundance of species was the Asian black-spined toad D. melanostictus in Sumbawa (114.81 ind/100 person-hours, Fig. 6). While the lowest relative abundance was the smooth-fingered narrowmouthed frog Kaloula baleata and the common four- 
clawed gecko Gehyra mutilata in Komodo Island (0.36 ind/100 person-hours each). The crab-eating frog
Fejervarya cancrivora was the most abundant amphibian in Rinca and coastal Flores.

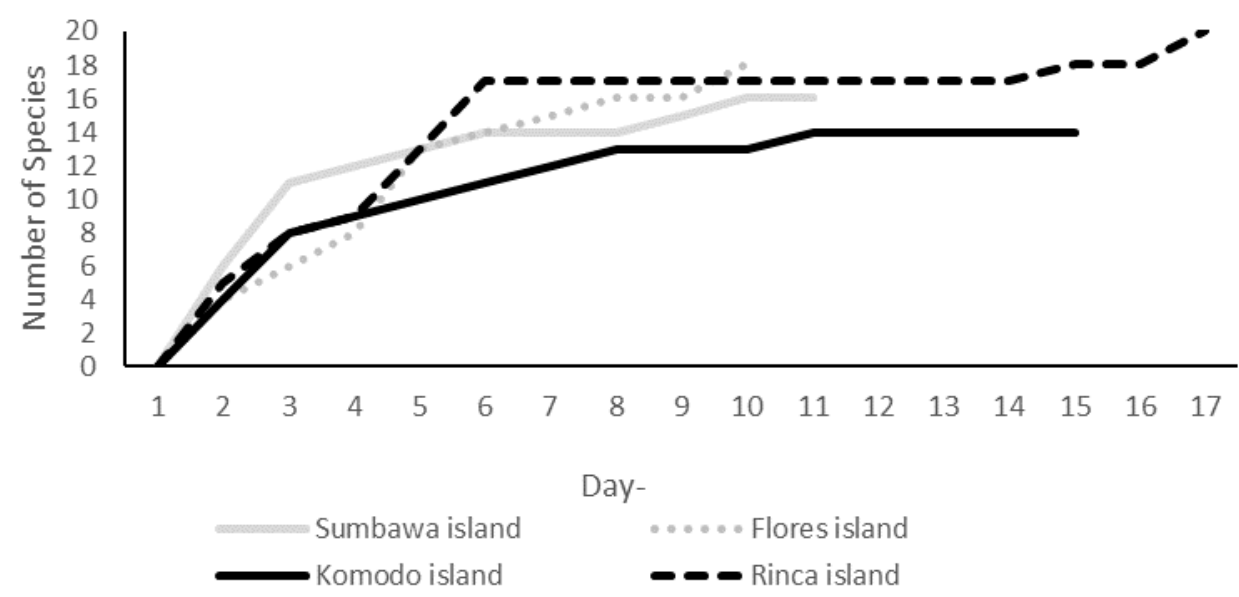

Figure 4 Species cumulative curves for amphibians and reptiles for each island
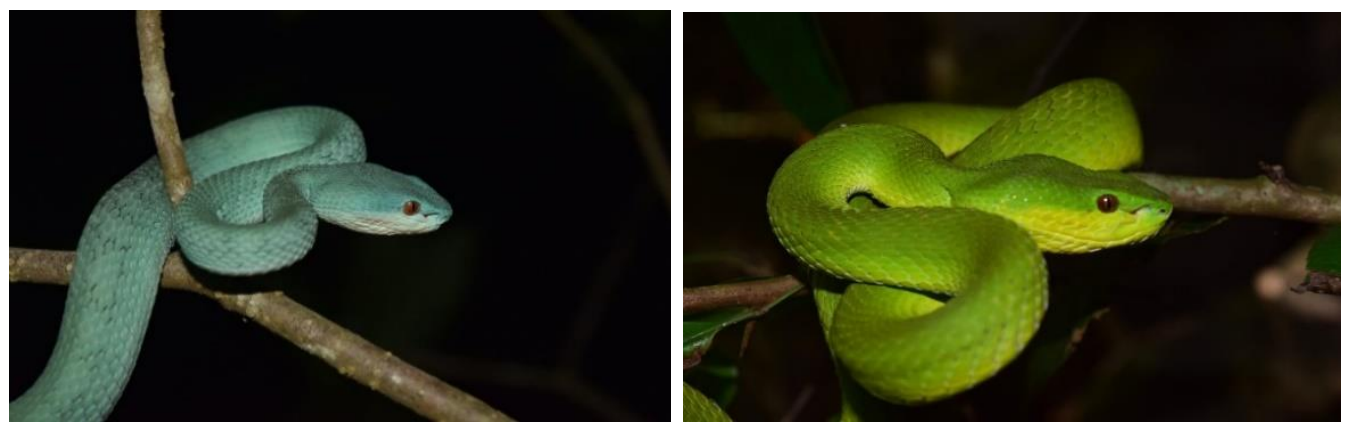

Figure 5 Color differences in Trimeresurus insularis; left: bluish-green color on Komodo Island and right: green coloration, the common coloration
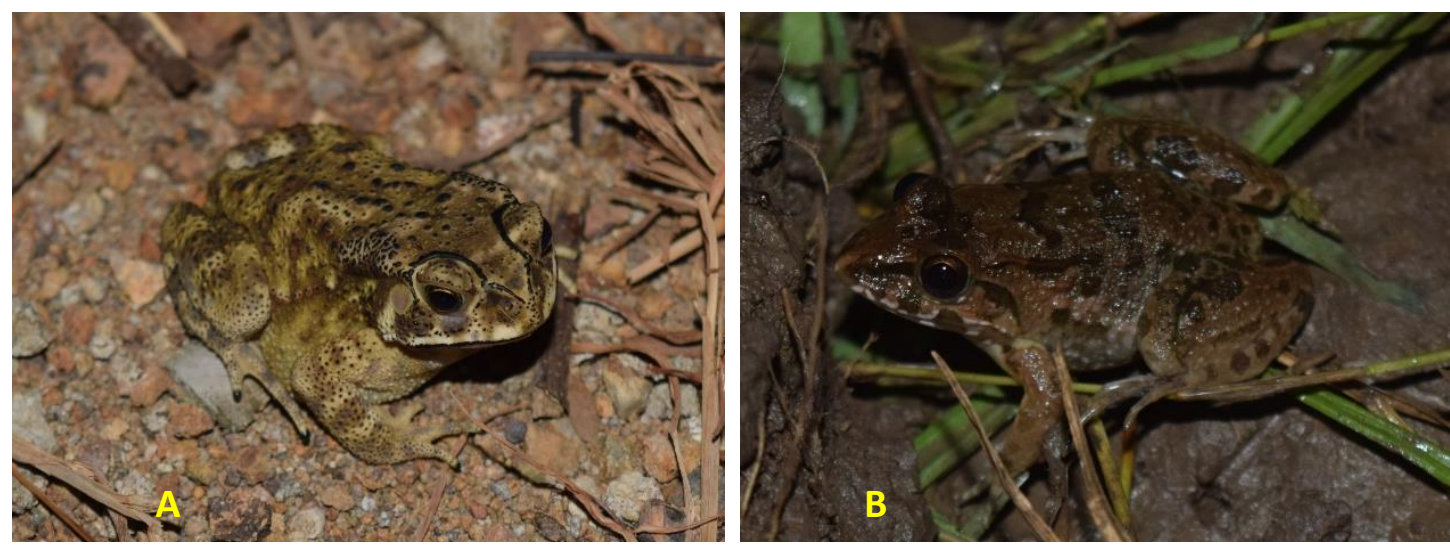

Figure 6 The Asian black-spined toad (D. melanostictus) (A) is the most abundant toad in Sape (left) and considered a threat if it arrives in Komodo National Park, while the crab-eating frog ( $F$. cancrivora) (B) might be a new immigrant to Komodo National Park 
There has been a concern that the Asian common toad (Duttaphrynus melanostictus), considered as an alien species for the eastern part of Indonesia, might have been distributed in Komodo National Park (Reilly et al., 2017). However, there is no evidence that the species has been found in the national park, although it was abundant in Sape (Kennedi et al., 2020). There is a possibility that the absence of D. melanostictus in Komodo National Park is due to its intolerance to salinity and extreme dryness. Research has shown that D. melanostictus tadpole is unable to withstand salinity (Strahan, 1953) compared to $F$. cancrivora (Dunson, 1977). Research by Mogali et al. (2017) has shown that the tadpole of $D$. melanostictus has the plasticity to adapt with desiccation by increasing its metamorphic process but at the same time decreasing its body size. However, Mogali et al. (2017) showed that the tadpole of D. melanostictus still needs a minimum threshold period to complete development, with a minimum of 20 days. The rain-filled ephemeral water bodies in Komodo and Rinca islands and Labuan Bajo might not sustain enough time for $D$. melanostictus tadpole to survive and metamorphose. On the contrary, the wet condition of Sape during research might explain the relatively high abundance of this toad in the area.

During the survey, the crab-eating frog ( $F$. cancrivora) was spotted in Loh Buaya and Loh Baru at Rinca Island (Fig. 6). The first encounter was on 15 March 2018 in Loh Buaya; the frog was calling in the water-buffalo mud puddle. There are two other records on the occurrence of this frog. Gilbert (2020) has found these species in April 2018, and Somaweera et al. (2018) also reported this species, although it was not clear the exact location. This species distributes widely in Asia (Islam et al., 2008) and adapts to a wide range of salinities (Dunson, 1977). It is unclear whether $F$. cancrivora has been established in Rinca for a long time or is a recent immigrant.

Table 2 Relative abundance (individual/100 person-hours) of herpetofauna at Komodo National Park and its surrounding areas based on islands. Data for amphibians were reported by Kennedi et al. (2020) but miscalculated as individual/person-hours.

\begin{tabular}{|c|c|c|c|c|c|}
\hline No & Scientific Name & Komodo Island & Rinca Island & Coastal Flores & Coastal Sumbawa \\
\hline \multicolumn{6}{|c|}{ Amphibians } \\
\hline 1 & Duttaphrynus melanostictus & - & - & - & 114.81 \\
\hline 2 & Fejervarya cancrivora & - & 12.12 & 66.67 & 81.48 \\
\hline 3 & Fejervarya limnocharis & - & - & 4.00 & 9.26 \\
\hline 4 & Limnonectes kadarsani & - & - & 21.33 & - \\
\hline 5 & Kaloula baleata & 0.36 & 1.21 & 18.67 & 3.70 \\
\hline 6 & Oreophryne jeffersoniana & - & - & 5.33 & - \\
\hline 7 & Polypedates leucomystax & - & - & 4.00 & 5.56 \\
\hline \multicolumn{6}{|c|}{ Reptiles } \\
\hline 8 & Gekko gecko & 1.44 & 1.62 & 6.67 & 16.67 \\
\hline 9 & Hemidactylus frenatus & 16.22 & 7.68 & 7.68 & 24.07 \\
\hline 10 & Hemidactylus platyurus & 14.05 & 8.48 & 2.67 & 14.81 \\
\hline 11 & Gehyra mutilata & 0.36 & 0.81 & - & 1.85 \\
\hline 12 & Cyrtodactylus darmandvillei & 7.93 & 5.66 & 12.00 & 7.41 \\
\hline 13 & Sphenomorphus melanopogon & 7.21 & 6.06 & 6.06 & - \\
\hline 14 & Sphenomorphus striolatus & 9.73 & 9.29 & 9.29 & 1.85 \\
\hline 15 & Cryptoblepharus renschi & 2.52 & 1.62 & 1.62 & - \\
\hline 16 & Emoia similis & - & 3.64 & - & - \\
\hline 17 & Lamprolepis smaragdina & - & - & 2.67 & - \\
\hline 18 & Draco boschmai & - & - & - & 1.85 \\
\hline 19 & Lycodon capucinus & 3.60 & 3.64 & 1.33 & 7.41 \\
\hline 20 & Dendrelaphis inornatus & 1.08 & 0.81 & 1.33 & - \\
\hline 21 & Coelognathus subradiatus & - & - & - & 1.85 \\
\hline 22 & Indotyphlops braminus & - & 0.81 & - & - \\
\hline 23 & Trimeresurus insularis & 0.72 & 1.62 & 28.00 & 3.70 \\
\hline 24 & Malayopython timoriensis & - & 0.40 & - & - \\
\hline 25 & Malayopython reticulatus & - & - & 1.33 & - \\
\hline 26 & Cerberus schneiderii & - & - & - & - \\
\hline 27 & Laticauda colubrina & - & - & - & - \\
\hline 28 & Varanus komodoensis & 2.16 & 1.62 & - & - \\
\hline 29 & Varanus salvator & - & - & 1.33 & 11.11 \\
\hline
\end{tabular}


The highest abundance of reptiles in Komodo Island was the common house gecko, Hemidactylus frenatus followed by the flat-tail gecko $H$. platyurus, the Flores banded skink Sphenomorphus striolatus, and Lesser Sunda dark-throated skink S. melanopogon. All four species were found in all survey sites on Komodo Island and also found in coastal Flores and Sumbawa (Table 2, Fig. 7).

\section{Diversity and Community Similarity}

The highest index of Shannon-Wiener diversity was found in Loh Buaya (Rinca Island) $\left(\mathrm{H}^{\prime}=2.42\right)$, while the lowest index was in Komodo Village $\left(\mathrm{H}^{\prime}=1.74\right)$. The highest evenness index was in Sape, while the lowest was in Rinca Village $(\mathrm{E}=0.38)$.
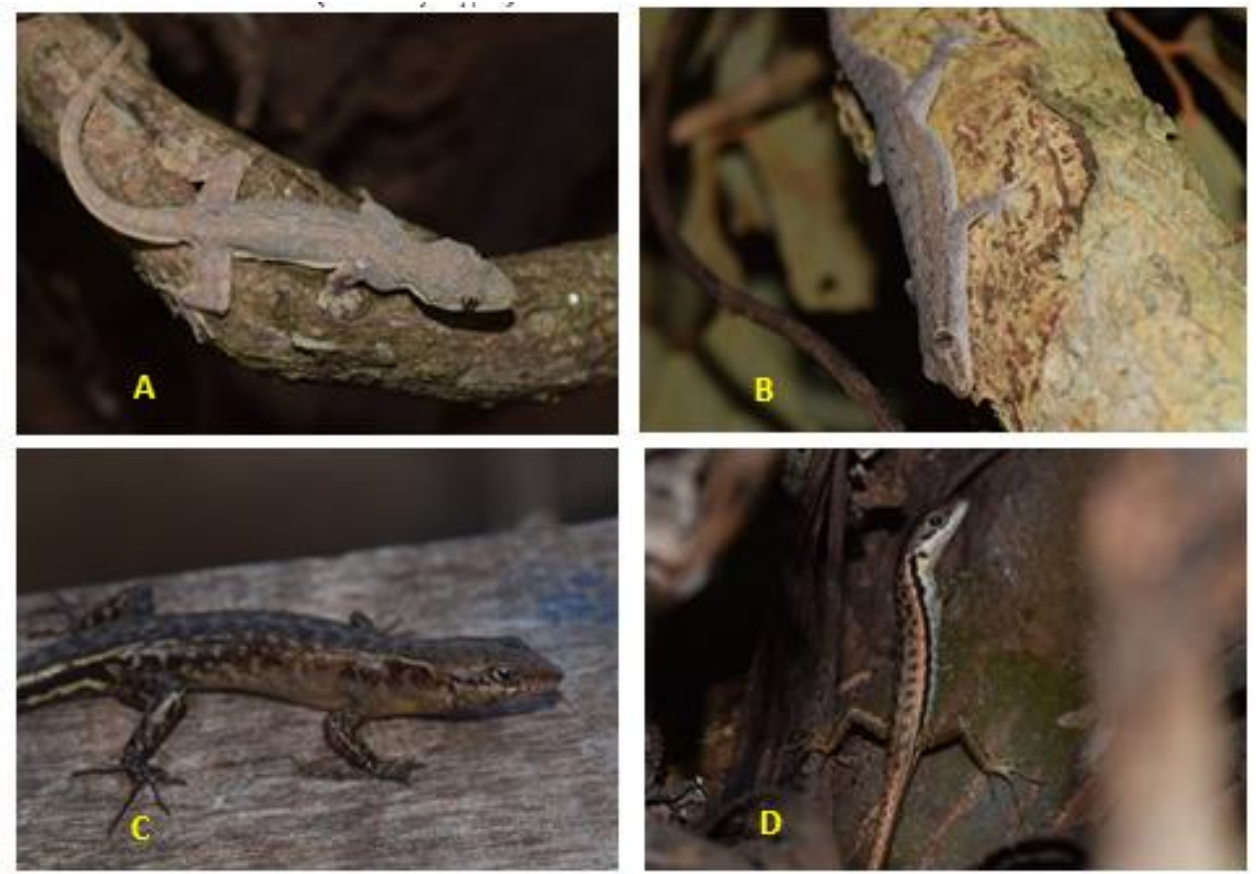

Figure 7 The four most abundant reptiles in Komodo Island: Hemidactylus frenatus (A), H. platyurus (B), Sphenomorphus striolatus (C), and S. melanopogon (D).

Table 3 Number of species, number of individuals, diversity, and evenness index of herpetofauna of Komodo, Rinca, coastal Flores, and coastal Sumbawa. Note: KPK=Kampung Komodo, LLG=Loh Liang, LBR=Loh Baru, LBY=Loh Buaya, KPR=Kampung Rinca, LWU=Loh Wau, CMB=Desa Cumbi, LBJ=Labuan Bajo, and SAP=Sape.

\begin{tabular}{|c|c|c|c|c|c|c|c|c|c|}
\hline \multirow{2}{*}{ Index } & \multicolumn{3}{|c|}{ Komodo Island } & \multicolumn{3}{|c|}{ Rinca Island } & \multicolumn{2}{|c|}{$\begin{array}{l}\text { Coastal } \\
\text { Flores }\end{array}$} & \multirow{2}{*}{$\begin{array}{c}\begin{array}{c}\text { Coastal } \\
\text { Sumbawa }\end{array} \\
\text { SAP }\end{array}$} \\
\hline & $\begin{array}{l}\mathrm{KP} \\
\mathrm{K}\end{array}$ & $\begin{array}{c}\mathrm{LL} \\
\mathrm{G}\end{array}$ & $\begin{array}{c}\mathrm{LW} \\
\mathrm{U}\end{array}$ & $\begin{array}{c}\text { LB } \\
Y\end{array}$ & $\begin{array}{c}\mathrm{KP} \\
\mathrm{R}\end{array}$ & $\begin{array}{c}\mathrm{LB} \\
\mathrm{R}\end{array}$ & CMB & LBJ & \\
\hline Number of Species & 11 & 10 & 8 & 17 & 10 & 14 & 9 & 13 & 17 \\
\hline Number of individuals & 66 & 70 & 52 & 71 & 47 & 51 & 85 & 66 & 166 \\
\hline $\begin{array}{c}\text { Shannon Wiener Diversity Index } \\
\left(\mathrm{H}^{\prime}\right)\end{array}$ & 1.74 & 1.99 & 1.86 & 2.42 & 1.79 & 2.31 & 1.87 & 1.94 & 1.95 \\
\hline Evenness Index $(\mathrm{E})$ & 0.40 & 0.47 & 0.47 & 0.55 & 0.43 & 0.59 & 0.42 & 0.46 & 0.38 \\
\hline
\end{tabular}




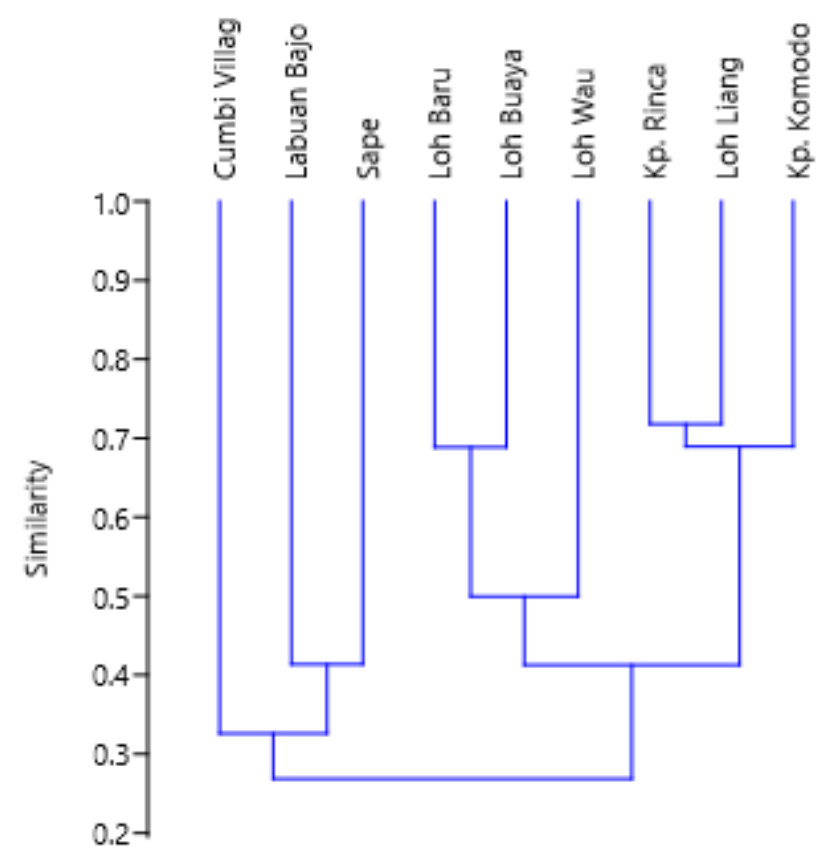

Figure 8 Dendrogram of paired group analysis depicting the Bray-Curtis similarity based on the occurrence and abundance of amphibian and reptile species in all locations.

The Bray-Curtis similarity is primarily used to quantify the differences in species populations between different species. Based on figure 8 There were two clusters of similarity between locations. The Locations at Komodo Island and Rinca Island belong to one cluster (with similarity of 0.45 ), where similar species can be found in locations within the islands. The similarity of ecosystems and the close distance between Komodo and Rinca Islands might explained the higher community similarity between these islands.

The community assemblages of coastal Flores and Sumbawa has formed a cluster with low similarity (0.35). This cluster is linked with Komodo-Rinca Islands cluster with lower similarity (0.28). The Bray-Curtis similarity indices distinguished compositional similarity of species assemblages by matching abundances of species in each community (Chao et al., 2005). Almost $80 \%$ of species found in Komodo and Rinca Island were found either in coastal Flores or Sumbawa. However, there were differences in abundance. In coastal Sumbawa, one species tended to dominate, whereas there was no dominance in other locations. The resulting clustering showed that the community assemblages between Komodo and Rinca Islands with adjacent coastal areas differed in abundance.

The number of species on an island is influenced by the size of the island and the distance to the main island, which both affect the rate of extinction and immigration (MacArthur \& Wilson, 1967). Flores and Sumbawa, which are large (main) islands, should have higher species diversity than smaller islands such as Rinca and Komodo. However, our sampling was restricted to the selected coastal area in Flores and Sumbawa, which is only a tiny part of the entire island. Small islands usually have fewer species richness than the mainland, which has been explained by the theory of island biogeography (MacArthur \& Wilson, 1967), as shown in this result.

All species in Rinca and Komodo Island were distributed either in Flores or Sumbawa, or both. For instance, V. komodoensis is not only found in Komodo National Park but also on Flores Island, i.e., Longos Island, Waewuul Nature Reserve, Tanjung Karita, and North Flores (Ariefiandy et al. 2021; Ciofi and De Boer, 2014). C. schneiderii, E. similis, I. braminus, and $M$. timoriensis were also found in Flores and Sumbawa (Reilly et al. 2020). Although the occurrence of amphibian and reptile in Komodo National Park are mostly secure due to the protected status of the area, it might be different on the mainland. For instance, Komodo distribution in Flores is mostly non-protected areas and at risk from anthropogenic threats (Ariefiandy et al., 2021; Azmi et al., 2021; Ciofi et al., 2002) and climate change (Jones et al., 2020).

\section{A complete list of reptile and amphibian of Komodo National Park}

Based on this research, combined with the report by Auffenberg (1980), Wahyuni (2012), and Somaweera et al. (2018), the herpetofauna of Komodo National Park comprised of four species of amphibians (Table 4, Figure 6) and 39 species of reptiles (Table 4). Our survey yielded only two species of amphibian out of three species reported by Auffenberg (1980) in Komodo Island 
and about half of the Komodo Island reptiles and mostly terrestrial species. $O$. jeffersoniana, an endemic species was notably absent during our research in Komodo Island, although it was recorded in coastal Flores.

Wahyuni (2012) did not find any amphibian in Padar, a smaller and mostly dry island in Komodo National Park compared to Komodo and Rinca. Four species of reptiles reported by Wahyuni (2012) were absent in Komodo and Rinca island: B. hoeseli, and $C$. subradiatus (both endemic of Nusa Tenggara), $N$. sputatrix, and $C$. yulensis. There is a possibility of misidentification of Wahyuni for $C$. yulensis. The species was only reported from Yule Island in Papua New
Guinea (Horner, 2007). No specimens or pictures were available from Wahyuni's work; thus, we omitted $C$. yulensis from the list of reptiles and amphibian species of Komodo National Park. A comparison between a list of herpetofauna published by Auffenberg (1980) on the Komodo Island showed that our study result was also lower. From 1969 through 1970, 1971, and 1973, Auffenberg discovered 30 species of herpetofauna, whereas our study only found 14 species in Komodo Island. However, three species found in this study ( $F$. cancrivora, $M$. timoriensis, and E. similis) were not reported by Wahyuni (2012) in Padar or by Auffenberg (1980) in Komodo Island.

Table 4 List of amphibian and reptile species in three main islands of Komodo National Park based on Auffenberg 1980 (1), Wahyuni 2012 (2), this study (3), and Somaweera et al. 2018 (4).

No Species $\quad{\text { Komodo Island } \quad \text { Rinca Island }^{3}}_{\text {Padar island }}^{2} \quad$ Komodo NP $^{4}$

\begin{tabular}{cl}
\hline AMPHIBIANS \\
1 & Fejervarya cancrivora \\
2 & Kaloula baleata \\
3 & Kaloula pulchra \\
4 & Oreophryne jeffersoniana \\
\hline REPTILES \\
Geckoes \\
1 & Cyrtodactylus darmandvillei \\
2 & Cyrtodactylus laevigatus \\
3 & Gehyra mutilata \\
4 & Gekko gecko \\
5 & Hemidactylus frenatus \\
6 & Hemidactylus platyurus \\
7 & Hemiphyllodactylus typus \\
8 & Lepidodactylus lugubris
\end{tabular}

Skinks

9 Cryptoblepharus burdeni

10 Cryptoblepharus renschi

11 Emoia similis

12 Eremiascincus emigrans

13 Eutropis multifasciata

14 Sphenomorphus melanopogon

15 Sphenomorphus schlegeli

16 Sphenomorphus striolatus

Other lizards

17 Draco boschmai

18 Dibamus novaeguineae

19 Varanus komodoensis

20 Varanus salvator

yes $^{1,3}$
yes $^{1}$
yes $^{1,3}$
yes $^{1,3}$
yes $^{1,3}$
yes $^{1,3}$
no
yes $^{1}$
yes $^{1}$
yes $^{1,3}$
yes $^{1}$
yes $^{1}$
yes $^{1}$
yes $^{1,3}$
yes $^{1}$
yes $^{1,3}$
yes $^{1}$
yes $^{1}$
yes $^{1,3}$
no $^{1}$

yes

yes

yes

no yes

no

yes

yes $^{3}$

yes

no

yes

no

no

no

yes

yes $^{1}$

no

yes

Sea turtles 


\begin{tabular}{|c|c|c|c|c|c|}
\hline No & Species & Komodo Island & Rinca Island $^{3}$ & Padar island $^{2}$ & Komodo NP \\
\hline 21 & Chelonia mydas & yes $^{1}$ & NA & no & yes \\
\hline 22 & Eretmochelys imbricata & yes $^{1}$ & NA & no & yes \\
\hline \multicolumn{6}{|c|}{ Crocodiles } \\
\hline 23 & Crocodylus porosus & yes $^{1}$ & NA & no & yes \\
\hline \multicolumn{6}{|c|}{ Sea snakes } \\
\hline 24 & Laticauda colubrina & yes $^{1,3}$ & yes & no & yes $^{a}$ \\
\hline \multicolumn{6}{|c|}{ Aquatic snakes } \\
\hline 25 & Acrochordus granulatus & yes $^{1}$ & NA & no & yes \\
\hline 26 & Cerberus schneiderii & yes $^{1}$ & yes & yes & yes \\
\hline \multicolumn{6}{|c|}{ Land and tree snakes } \\
\hline 27 & Boiga hoeseli & yes $^{1}$ & no & yes & yes \\
\hline 28 & Coelognathus subradiatus & yes $^{1}$ & yes & yes & yes \\
\hline 29 & Dendrelaphis inornatus & yes $^{1,3}$ & yes & yes & yes \\
\hline 30 & Lycodon capucinus & yes $^{1,3}$ & yes & yes & yes \\
\hline 31 & Psammodynastes pulverulentus & yes $^{1}$ & no & no & yes \\
\hline 32 & Malayopython timoriensis & no & yes & yes & yes \\
\hline 33 & Naja sputatrix & yes $^{1}$ & no & no & yes \\
\hline 34 & Daboia siamensis & yes $^{1}$ & no & no & yes \\
\hline 35 & Trimeresurus insularis & yes $^{1,3}$ & yes & yes & yes \\
\hline \multicolumn{6}{|c|}{ Burrowing snakes } \\
\hline 36 & Cylindrophis opisthorhodus & no & no & no & yes \\
\hline 37 & Indotyphlops braminus & yes $^{1}$ & yes & yes & yes \\
\hline 38 & Indotyphlops schmutzi & yes $^{1}$ & no & no & yes \\
\hline 39 & Sundatyphlops polygrammicus & yes $^{1}$ & no & no & yes \\
\hline
\end{tabular}

Note: NA=Not Available (the survey was not carried out in its habitat).

The absence of several species in contrast to Auffenberg's (1980) was influenced by total search effort and seasonality. One amphibian and 17 reptiles were absent in this research as listed in Table 4. Auffenberg (1980) were based on almost three years' fieldwork, including the rainy season and the dry season, thus increasing the opportunity to get more species. Our survey was conducted at the end of the wet season. It is recommended that other sampling should account for the rainy season, especially during December-January, during the highest rainfall, due to the possibility of different encounters between the rainy season and dry season.

This survey did not record several marine reptiles' species because it mostly focused on terrestrial herpetofauna habitat. Based on Jackknife's calculations, there was still a possibility that more herpetofauna can be found on Komodo Island.

\section{CONCLUSION}

Our field surveys were recorded 22 species of reptiles and seven species of amphibians, but only 18 species of reptiles and two species of amphibian were from Komodo and Rinca Island. All species found in Komodo, and Rinca Island are also distributed in the mainland (Flores Island), and $80 \%$ of species of Komodo and Rinca Island were also recorded from coastal Flores and Sumbawa. The highest Shannon-Wiener diversity index (2.14) was in Loh Buaya (Rinca). The number of species in Loh Buaya was similar to Sape in coastal Sumbawa; however, the evenness index was higher (0.55) in Loh Buaya, which showed no dominant species in this area. Komodo National Park is home to 39 species of reptiles and four species of amphibians. As a conservation area, this national park is essential to ensure the survival of herpetofauna. Moreover, it serves as a habitat for protected species and highly endemic reptiles from the Lesser Sunda Islands. 


\section{ACKNOWLEDGEMENTS}

The Komodo Survival Program and University of Florence provided funding for this research (UFK and MDK). We thank the Komodo National Park office, especially the Head of the National Park, Bapak Budi, and staff of Komodo National Park: M. R. Panggur, B. Darmawan, and Andan for the assistance. We thank D. Purwananda and C. Ciofi for their help and advice during the research. We are grateful for the support of F. S. Ramadani, Mufti, Adam, pak Sidik, and teachers of SMK Kelautan Sape for their assistance in the field. Fieldwork by UFK in the national park has been granted through the SIMAKSI number SI. 24/T.17/TU/2/2018.

\section{REFERENCES}

Ardiantiono, Jessop TS, Purwananda D, Ciofi C, Jeri Imansyah M, Panggur MR, Ariefiandy A. 2018. Effects of human activities on Komodo dragons in Komodo National Park. Biodiversity and Conservation 27: 3329-3347.

AmphibiaWeb. 2020. University of California, Berkeley, CA, USA. https:// https://amphibiaweb.org. [access date: 29 June 2020].

Ariefiandy A, Purwandana D, Natali C, Imansyah MJ, Surahman M, Jessop TS, Ciofi C. 2015. Conservation of Komodo dragons Varanus komodoensis in the Wae Wuul nature reserve, Flores, Indonesia: a multidisciplinary approach. International Zoo Yearbook, 49: 67-80.

Ariefiandy A, Purwandana D, Azmi M, Nasu SA, Mardani J, Ciofi C, Jessop TS. 2021. Human activities associated with reduced Komodo dragon habitat use and range loss on Flores. Biodiversity and Conservation 30:461-79.

Auffenberg W. 1980. The herpetofauna of Komodo, with notes on adjacent areas. Bulletin of the Florida States Museum Biological Sciences 25(2): 40-150.

Azmi M, Nasu SA, Kasim AM, Ariefiandy A, Purwandana D, Ciofi C, Jessop TS. 2021. Incidences of Road Kills and Injuries of Komodo Dragons Along the North Coast of Flores Island, Indonesia. Herpetological Conservation and Biology 16(1): 1116.

Bray RJ, Curtis JT. 1957. An ordinary of the upland forest communities of southern Wisconsin. Ecol. Monogr. 27: 326-349.

Brower JE, Zar JH. 1997. Field and Laboratory Methods for General Ecology. Brown. Iowa.

Chao A, Chazdon RL, Colwell RK, Shen T-J. 2005. A new statistical approach for assessing similarity of species composition with incidence and abundance data: A new statistical approach for assessing similarity. Ecology Letters 8: 148-159.

Ciofi C, Beaumontf MA, Swingland IR, Bruford MW. 1999. Genetic divergence and units for conservation in the Komodo dragon Varanus komodoensis.
Proceedings of the Royal Society of London. Series B: Biological Sciences 266: 2269-2274.

Ciofi C, De Boer M. 2004. Distribution and conservation of the komodo monitor (Varanus komodoensis). Herpetological Journal 14: 99-107.

Ciofi C, Smith BR, Hutchins M. 2002. Conservation in situ and ex situ contributions. In Komodo Dragon: Biology and Conservation (eds. Murphy JB, Ciofi C. De La Panouse C, Walsh T. Smothsonian Institution Press. Washington. Pp: 211-230.

Clemann N, Rowe KM, Rowe KC, Raadik T, Gomon M, Menkhorst P, Sumner J, Bray D, Norman M, Melville J. 2014. Value and impacts of collecting vertebrate voucher specimens, with guidelines for ethical collection. Memoirs of Museum Victoria 72: 141151.

De Lang R. 2011. The snake of the lesser sunda island (Nusa Tenggara) Indonesia. Asian Herpetological Research 2(1): 46-54.

Dunson WA. 1977. Tolerance to high temperature and salinity by tadpoles of the Philippine frog, Rana cancrivora. Copeia 1977: 375-378.

Frost DR. 2020. Amphibian Species of the world Ver 6.1 .

https://amphibiansoftheworld.amnh.org/index.php. [access date: 29 June 2020].

Gilbert JB, Ocock J, Martinez CAP, Riley JL. 2020. Fejervarya cancrivora (Crab-eating frog) Dunging (Natural History Notes). Herpetological review 51(1): 97-98.

Heltse JF, Forester NE. 1983. Estimating species richness using the jackknife procedure. Biometrics 39: 1-11.

Heyer WR, Donnelly MA, McDiarmid RW, Hayek LC, Foster MS. 1994. Measuring and Monitoring Biological Diversity: Standard Methods for Amphibians. Smithsonian Institution Pr. Washington DC.

Horner P. 2007. Systematics of the snake-eyed skinks, Cryptoblepharus Wiegmann (Reptilia: Squamata: Scincidae) - an Australian-based review. The Beagle, Records of the Museums and Art Galleries of the Northern Territory Supplement 3: 21-198.

Hulme PE, Bacher S, Kenis M, Klotz S, Kuhn I, Minchin D, Nentwig W, Olenin S, Panov V, Pergl J, Pysek P, Roques A, Sol D, Solarz W, Vila M. 2008. Grasping at the routes of biological invasions: a framework for integrating pathways into policy. Journal of Applied Ecology 45: 403-414.

Islam MM, Kurose N, Khan MMR, Nishizawa T, Kuramoto M, Alam MS, Hasan M, Kurniawan N, Nishioka M, and Sumida M. 2008. Genetic divergence and reproductive isolation in the genus Fejervarya (Amphibia: Anura) from Bangladesh inferred from morphological observations, crossing experiments, and molecular analyses. Zool Sci 25: 1084-1105. 
Jones AR, Jessop TS, Ariefiandy A, Brook BW, Brown SC, Ciofi C, Benu YJ, Purwandana D, Sitorus T, Wigley TML, Fordham DA. 2020. Identifying island safe havens to prevent the extinction of the World's largest lizard from global warming. Ecology and Evolution 10: 10492-10507.

Jessop TS, Ariefiandy A, Purwandana D, Ciofi C, Imansyah J, Benu YJ, Fordham DA, Forsyth DM, Mulder RA, Phillips BL. 2018. Exploring mechanisms and origins of reduced dispersal in islands Komodo dragons. Proc. R. Soc. B 285: 20181829.

Kennedi UF, Kusrini MD, Mardiastuti A, Ariefiandy A. 2020. Invasive toads are close to but absent from Komodo National Park. BIO Web of Conferences 19(1): 00017.

Kusrini MD. 2013. Panduan Bergambar Identifikasi Amfibi Jawa Barat. Fakultas Kehutanan IPB. Bogor.

MacArthur RH, Wilson EO. 1967. The Theory of Island Biogeography. Princeton University Press. Princeton.

Mogali S, Saidapur S, Shanbhag B. 2017. Influence of desiccation threat on the metamorphic traits of the Asian common toad, Duttaphrynus melanostictus (Anura). Acta Herpetologica 12 (2): 175-180.

Monk KA, De Freter, Reksodihardjo G, Lilley. 1997. The Ecology of Nusa Tenggara and Maluku (The Ecology of Indonesia Series Volume V). Periplus edition. Singapore.

Purwandana D, Ariefiandy A, Imansyah M., Seno A, Ciofi C, Letnic M, Jessop TS. 2016. Ecological allometries and niche use dynamics across Komodo dragon ontogeny. The Science of Nature 103(3-4): 111.

Reilly SB, Wogan G, Arida E, Iskandar DT, McGuire J. 2017. Toxic toad invasion of Wallacea: a biodiversity hotspot characterized by extraordinary endemism. Global Change Biology 23(12): 1-3.

Reilly SB, Stubbs AL, Arida E, Arifin U, Bloch L, Hamidy A, Harmon K, Hykin S, Karin BR, Ramadhan G, Iskandar DT, McGuire JA. 2020. New Island Records for Anurans and Squamates from the Lesser Sunda Archipelago. Herpetological Review 51(4): 785-789.

Somaweera R, Azis A, Resa E, Panggur MR, Saverinus D, Muga K. 2018. Amphibians and Reptiles of Komodo National Park. Aaranya Wildlife Odysseys. Australia.

Spellerberg IF, Fedor PJ. 2003. A tribute to Claude Shannon (1916-2001) and a plea for more rigorous use of species richness, species diversity, and the 'Shannon-Wiener' Index. Global Ecology \& Biogeography 2003: 177-179.

Stirling G, Wilsey B. 2001. Empirical relationships between species richness, evenness, and proportional diversity. The American Naturalist 158 (3): 286-299.

Strahan R. 1953. The effect of salinity on the survival of larvae of Bufo melanostictus Schneider. Copeia 1957(2): 146-147.

Uetz P, Etzold T. 1996. The EMBL/EBI reptile database. Herpetological Review 27(4): 174-175.

Wahyuni SR. 2012. Keanekaragaman jenis and sebaran spasial reptil di Pulau Padar, Taman Nasional Komodo. Skripsi. Institut Pertanian Bogor. Bogor. 
APPENDICES

Appendix 1. Specimens deposited at Museum Zoological Bogor (MZB).

\begin{tabular}{clllll}
\hline No & Species & Code & MZB & Site & Island \\
\hline 1 & Cryptoblepharus renschi & Lace & 14906 & Loh Wau & Komodo \\
2 & Cryptoblepharus renschi & Lace & 14907 & Loh Wau & Komodo \\
3 & Cyrtodactylus darmandvillei & Lace & 14897 & Kp. Komodo & Komodo \\
4 & Cyrtodactylus darmandvillei & Lace & 14898 & Loh Liang & Komodo \\
5 & Sphenomorphus melanopogon & Lace & 14903 & Kp. Komodo & Komodo \\
6 & Sphenomorphus melanopogon & Lace & 14904 & Loh Buaya & Rinca \\
7 & Sphenomorphus striolatus & Lace & 14901 & Kp. Komodo & Komodo \\
8 & Sphenomorphus striolatus & Lace & 14905 & Loh Buaya & Rinca \\
9 & Sphenomorphus striolatus & Lace & 14902 & Loh Buaya & Rinca \\
10 & Emoia similis & Lace & 14908 & Loh Buaya & Rinca \\
11 & Emoia similis & Lace & 14909 & Loh Buaya & Rinca \\
12 & Gehyra mutilata & Lace & 14910 & Sape & Sumbawa \\
13 & Hemidactylus frenatus & Lace & 14899 & Kp. Komodo & Komodo \\
14 & Hemidactylus frenatus & Lace & 14900 & Kp. Komodo & Komodo \\
15 & Lycodon capucinus & Ophi & 6237 & Loh Liang & Komodo \\
16 & Indotyphlops braminus & Ophi & 6236 & Loh Buaya & Rinca \\
17 & Duttaphrynus melanostictus & Amph & 31740 & Sape & Sumbawa \\
18 & Duttaphrynus melanostictus & Amph & 31741 & Sape & Sumbawa \\
19 & Fejervarya cancrivora & Amph & 31738 & Loh Buaya & Rinca \\
20 & Fejervarya verruculosa & Amph & 31739 & Labuan Bajo & Flores \\
21 & Kaloula baleata & Amph & 31742 & Loh Buaya & Rinca \\
22 & Limnonectes kadarsani & Amph & 31743 & Wae Wuul & Flores \\
23 & Limnonectes kadarsani & Amph & 31744 & Wae Wuul & Flores \\
24 & Oreophryne jeffersoniana & Amph & 31745 & Wae Wuul & Flores \\
25 & Polypedates leucomystax & Amph & 31746 & Labuan Bajo & Flores \\
\hline & & & & &
\end{tabular}

